Provided for non-commercial research and education use. Not for reproduction, distribution or commercial use.

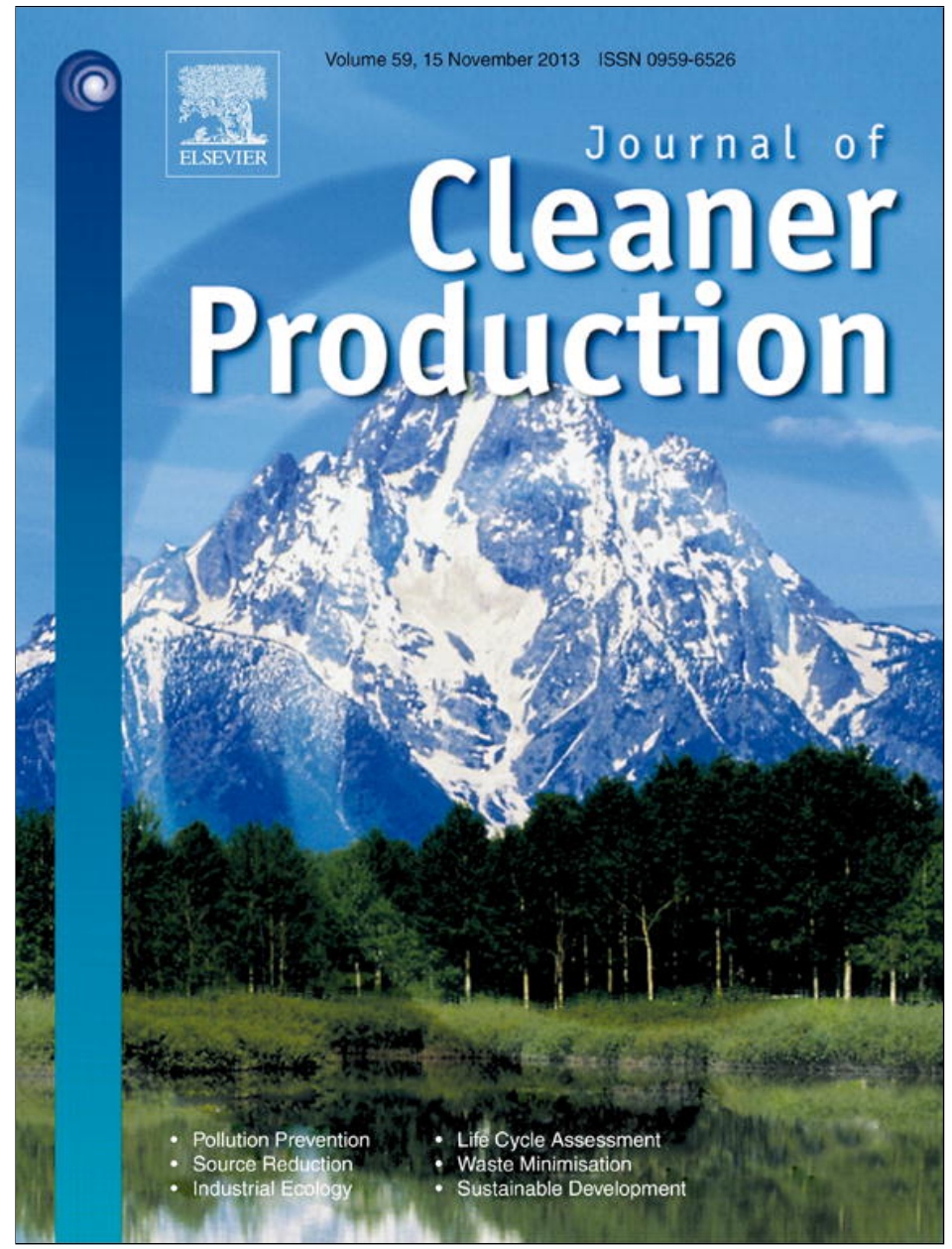

This article appeared in a journal published by Elsevier. The attached copy is furnished to the author for internal non-commercial research and education use, including for instruction at the authors institution and sharing with colleagues.

Other uses, including reproduction and distribution, or selling or licensing copies, or posting to personal, institutional or third party websites are prohibited.

In most cases authors are permitted to post their version of the article (e.g. in Word or Tex form) to their personal website or institutional repository. Authors requiring further information regarding Elsevier's archiving and manuscript policies are encouraged to visit:

http://www.elsevier.com/authorsrights 


\title{
Environmental influence of maize substitution by sorghum and diet presentation on goose foie gras production
}

\author{
J. Arroyo a,b,c,d ${ }^{\text {, L. Fortun-Lamothe }}{ }^{\mathrm{b}, \mathrm{a}, \mathrm{c}, *}$, A. Auvergne $^{\mathrm{a}, \mathrm{b}, \mathrm{c}}$, J.P. Dubois ${ }^{\mathrm{d}}$, F. Lavigne ${ }^{\mathrm{d}}$, \\ M. Bijja ${ }^{\mathrm{d}}$, J. Aubin ${ }^{\mathrm{e}}$ \\ a Université de Toulouse INPT ENSAT, UMR 1289 Tissus Animaux, Nutrition, Digestion, Ecosystème et Métabolisme, F-31326 Castanet-Tolosan Cedex, France \\ b INRA, UMR1289 Tissus Animaux, Nutrition, Digestion, Ecosystème et Métabolisme, F-31326 Castanet-Tolosan, France \\ ${ }^{\mathrm{c}}$ Université de Toulouse INPT ENVT, UMR1289 Tissus Animaux, Nutrition, Digestion, Ecosystème et Métabolisme, F-31076 Toulouse, France \\ ${ }^{\mathrm{d}}$ ASSELDOR, Station d'expérimentation appliquée et de démonstration sur l'oie, La Tour de Glane, 24420 Coulaures, France \\ e INRA, Agrocampus Rennes, UMR1069, SAS, 65 rue de Saint-Brieuc, CS 84215, F-35042 Rennes Cedex, France
}

\section{A R T I C L E I N F O}

\section{Article history:}

Received 25 September 2012

Received in revised form

15 June 2013

Accepted 23 June 2013

Available online 5 July 2013

\section{Keywords:}

Goose

Sorghum

Maize

Foie gras

LCA

\begin{abstract}
A B S T R A C T
We studied the environmental consequences of cereal choice and form of presentation of the diet given to geese reared for foie gras production. A cradle-to-gate life cycle assessment of the production of $1 \mathrm{~kg}$ of foie gras was used to examine several feeding strategies for substituting maize by sorghum: during the growing-finishing and/or overfeeding period; in a complete pelleted diet or as whole grains. The data come from in-field management practices on representative French goose farms for the breeding, hatching and slaughtering stages of production, and in vivo experiments for the growing-finishing and overfeeding stages. The impact categories were calculated using the CML2 baseline method. Our data showed that the effects of cereal type on the environmental impact of foie gras were dependent on feed level and stage of inclusion. Birds fed exclusively with sorghum during both the growing-finishing period and the overfeeding period had lower environmental impacts than birds fed with maize, for all the potential impacts calculated (e.g. $-17 \%$ for global warming potential). A diet presented in a simplified form during the growing-finishing period had no effect on foie gras impacts when the cereal used was maize (difference between groups $<7 \%$ ), but increased them when it was sorghum (from $+16 \%$ for water use to $+22 \%$ eutrophication and acidification potential), due to higher bird mortality during the overfeeding period. These results suggest that changes in bird feeding practices could contribute to a more environmentally-friendly production system for foie gras if animal performance is note reduced. Hence, substitution of maize by sorghum can lessen the environmental impacts of foie gras production and thus offer a valuable alternative in response to water shortages in southern France, but its use in a simplified form hinges on prior improvement of rearing practices to limit subsequent mortality.
\end{abstract}

(C) 2013 Elsevier Ltd. All rights reserved.

\section{Introduction}

Food consumption accounts for about one third of the environmental impacts of households (Jungbluth et al., 2012). These impacts

\footnotetext{
Abbreviations: LCA, life cycle assessment; LCI, life cycle inventory; GWP, global warming potential; EP, eutrophication potential; AP, acidification potential; TE, terrestrial ecotoxicity; PEU, primary energy use; WU, water use; LO, land occupation; B, breeding; S, starter; GF, growing-finishing; O, overfeeding.

* Corresponding author. INRA, UMR1289 Tissus Animaux, Nutrition, Digestion, Ecosystème et Métabolisme, F-31326 Castanet-Tolosan, France. Tel.: +33 (0)5 0561 285318.

E-mail addresses: Laurence.Lamothe@toulouse.inra.fr, lamothe@toulouse.inra.fr (L. Fortun-Lamothe).
}

can be reduced by changing consumption patterns (buying locally, buying seasonally, eating vegetarian, reducing food waste etc.) or changing in production processes. Goose foie gras is a luxury product, consumed in small quantities mainly at parties and during the Christmas period. Worldwide foie gras production, from both duck and goose, amounts to 27,100 $\mathrm{t}$ (CIFOG, 2012), and is predominantly based in France (Arroyo et al., 2012b). The French are the largest foie gras consumers in the world (300 g per capita; CIFOG, 2012). Production of foie gras, like that of any other livestock product, has to address current environmental issues, especially as the consumption of luxury products is more heavily criticized than that of staples needed for human health (Jungbluth et al., 2012).

Feed is the main driver of environmental costs in poultry rearing (Boggia et al., 2010; Leinonen et al., 2012a, 2012b). Therefore, 
changing feeding practices, i.e. in choice of raw materials or form of diet presentation, so as to reduce the environmental costs of processing the diet or to improve the animals' feed efficiency (Lammers, 2011), can improve the sustainability of livestock production systems.

To obtain foie gras, geese are reared for fourteen weeks, with a starting period (S) of 6 weeks and a growing-finishing (GF) period of 8 weeks, and are then overfed for two weeks (Arroyo et al., $2012 b)$. As in other poultry production systems, the diet given during the rearing period, i.e. the $S+G F$ period, is generally presented as a complete pelleted feed. The diet used during the overfeeding period $(\mathrm{O})$ needs to be highly energy-rich, preferably in the form of starch, to induce steatosis of the liver. Since in France foie gras is produced in the same regions as maize, this cereal is usually used as the energy source during the rearing and overfeeding periods (Guéméné and Guy, 2004).

Here we evaluate the environmental impact of using sorghum (Sorghum bicolor (L.) Moench) as a substitute for maize in foie gras production. Sorghum has similar nutritional characteristics to maize (Sauvant et al., 2004), but is more drought-resistant, making it a promising candidate to reduce the vulnerability of French agriculture to water shortage (Amigues et al., 2006) by reducing the need for crop irrigation (Farré and Faci, 2006). In addition, increasing the range of raw materials lends greater flexibility to the production systems, and lessens the effects of product price fluctuations. Arroyo et al. (2013b) showed that sorghum could be used for goose feeding during the growing-finishing and/or the overfeeding stages of the foie gras production process. They showed that the use of sorghum during both the GF and $O$ periods resulted in an increased weight of fatty liver $(+11 \%)$ with no effect on mortality. By contrast, maize substitution by sorghum during the GF period only resulted in increased mortality during the overfeeding period (+13 pts). It therefore seemed of interest to evaluate the consequences of using a diet based on a cereal with a lower environmental impact, in terms mainly of global warming potential (GWP), primary energy use (PEU) and water use (WU), on the potential environmental impacts of foie gras production.

The form of the diet offered may also influence environmental performance (van der Werf et al., 2005). A poultry diet given in a simplified form, such as a mixture of whole grains and protein-rich pellets, could reduce the cost of manufacturing processes and thus reduce the environmental impacts of goose products, mainly GWP and PEU. It should also improve the social acceptability of breeding systems by ensuring the birds are fed with a diet considered more 'natural' (Gabriel et al., 2003). Arroyo et al. (2012a) showed that the use of whole seeds during the GF period improved animal feed efficiency $(+10 \%)$ during the GF period but increased mortality during the $\mathrm{O}$ period ( +10 to 20 pts depending on the cereal type). It therefore seemed of interest to determine whether the environmental gains on feed process and feed efficiency can compensate for the loss of system efficiency due to increased mortality.

Our study was accordingly designed to evaluate the effects of changes in goose feeding practices, from data obtained under experimental conditions, namely i) substitution of maize by sorghum in the diet fed during the GF and/or the $O$ period and ii) use of a cereal in a simplified form in the diet during the GF period on the environmental impact of geese foie gras production. For this purpose, life cycle assessment (LCA) was used for the first time to calculate the environmental impact of $1 \mathrm{~kg}$ of goose foie gras.

\section{Materials and methods}

\subsection{Diets}

During the GF period, four diets offered to the birds were tested: a complete pelleted diet containing $500 \mathrm{~g}$ of sorghum/kg (CS diet; nitrogen-corrected apparent metabolizable energy (AMEn) $11.29 \mathrm{MJ} / \mathrm{kg}$, crude protein (CP) $16.70 \%$ ); a simplified diet in the form of a mixture containing $500 \mathrm{~g}$ of protein-rich pellets and $500 \mathrm{~g}$ of sorghum whole seeds/kg (MS diet; AMEn $11.61 \mathrm{MJ} / \mathrm{kg}, \mathrm{CP}$ $14.30 \%$ ); a complete pelleted diet containing $500 \mathrm{~g}$ of maize $/ \mathrm{kg}$ (CM diet: AMEn $11.33 \mathrm{MJ} / \mathrm{kg}$, CP $16.40 \%$ ); or a simplified diet in the form of a mixture containing $500 \mathrm{~g}$ of protein-rich pellets and $500 \mathrm{~g}$ of maize mash/kg (MM diet; AMEn $11.48 \mathrm{MJ} / \mathrm{kg}$, CP 14.50\%). During the $O$ period, two diets were tested, the first composed of $967 \mathrm{~g}$ of maize/kg of dry matter (AMEn $18.55 \mathrm{MJ} / \mathrm{kg}, \mathrm{CP} 6.70 \mathrm{~g} / \mathrm{kg}$ ) and the second composed of $965 \mathrm{~g}$ of sorghum/kg of dry matter (AMEn $18.60 \mathrm{MJ} / \mathrm{kg}, \mathrm{CP} 7.80 \mathrm{~g} / \mathrm{kg}$ ). The overfeeding diets were in the form of a mixture of $42 \%$ of whole grain and $58 \%$ of ground grain mixed with water (667 or $754 \mathrm{~g} / \mathrm{kg}$ to the maize and sorghum diet, respectively). The amount of water added was higher in the sorghum than in the maize diet to permit easy overfeeding of both groups in spite of a lower water-holding capacity of the sorghum compared to maize. But feed distribution during overfeeding was based on dry matter to ensure similar dry matter intake. Diet composition is given in Table 1 .

For LCI, the feed production stage includes agricultural crops, feed-ingredient processing and manufacture. As described in Mosnier et al. (2011), secondary data on resource use and emissions associated with the production and delivery of several crop production inputs (fertilizers, pesticides, tractor fuel and agricultural machinery) came from the ecoinvent database version 2.0 (Nemecek and Kägi, 2007). For all crops, inputs used and yields were based on French government agricultural statistics (AGRESTE, 2010). We assumed that crop products and feed ingredients produced in France were transported by road, whereas products imported into France (e.g. soybean) were shipped from overseas to the port and then by road to the feed factory.

Maize was assumed to be produced in the Aquitaine region (southwest France), using irrigation and mineral fertilizers, while sorghum was assumed to be produced in the Midi-Pyrénées region (southwest France), without irrigation but with mineral fertilizers. The main inputs used, dry matter crop yields, nitrate-N emitted and the potential environmental impacts of maize and sorghum production are shown in Table 2. As expected, the environmental impacts of sorghum production were approximately $40 \%$ lower than those of maize, except for eutrophication potential $(\mathrm{EP} ;+18 \%)$ and land occupation (LO; $+33 \%$ ). More especially, GWP $(-38 \%)$, PEU $(-57 \%)$ and WU $(-93 \%)$ were lower for sorghum than maize.

For processes transforming crops into feed ingredients, data were based on Nemecek and Kägi (2007) for maize-drying and Jungbluth et al. (2007) for the production of soybean meal, rapeseed meal and oil. Data were also collected for salt (Althaus et al., 2007), monocalcium phosphate (LCA Food database, 2007), calcium carbonate (Nemecek and Kägi, 2007), vitamin/mineral premix and amino acids (Mosnier et al., 2011).

Many feed ingredients (e.g. soybean meal, rapeseed oil) are coproducts. For these ingredients, resource use and emissions were allocated according to the economic value of the co-products (de Vries and de Boer, 2010) coupled with extraction rates (FAO, 2002; ISTA, 2009).

Emissions to air were estimated according literature for $\mathrm{NH}_{3}$ (Nemecek and Kägi, 2007), $\mathrm{N}_{2} \mathrm{O}$ (IPCC, 2006) and $\mathrm{NO}_{x}\left(21 \%\right.$ of $\mathrm{N}_{2} \mathrm{O}$; Nemecek and Kägi, 2007), as well as $\mathrm{NO}_{3}$ losses to groundwater (Basset-Mens et al., 2007), and phosphate emissions to water (Nemecek and Kägi, 2007). The feed factory was assumed to be located in the Dordogne region of southwest France, $80 \mathrm{~km}$ from the GF and $\mathrm{O}$ units. Potential impacts of the experimental diets at the farm gate, i.e. including transport, are given in Table 1 . As expected, the substitution of maize by sorghum decreased the GWP ( $-19 \%$ and $-43 \%$ in GF and O diets, respectively), the PEU $(-25 \%$ 
Table 1

Ingredients and potential environmental impacts of the experimental diets.

\begin{tabular}{|c|c|c|c|c|c|c|c|c|}
\hline & \multicolumn{6}{|c|}{ Growing-finishing diet ${ }^{\mathrm{a}, \mathrm{b}}$} & \multicolumn{2}{|c|}{ Overfeeding diet ${ }^{\mathrm{c}}$} \\
\hline & \multicolumn{4}{|c|}{ Complete pelleted diets } & \multicolumn{2}{|c|}{ Mixture diets } & & \\
\hline & \multirow[t]{2}{*}{$\mathrm{CM}$} & \multirow[t]{2}{*}{ CS } & \multicolumn{2}{|l|}{ MM } & \multicolumn{2}{|l|}{ MS } & \multirow[b]{2}{*}{ Maize } & \multirow[b]{2}{*}{ Sorghum } \\
\hline & & & PRM & $\mathrm{CF}$ & PRS & SWS & & \\
\hline \multicolumn{9}{|l|}{ Ingredients (g/kg) } \\
\hline Maize & 500.0 & - & - & 1000.0 & - & - & $321.9^{\mathrm{d}}$ & - \\
\hline Sorghum & - & 500.0 & - & - & - & 1000.0 & - & $237.4^{\mathrm{e}}$ \\
\hline Wheat & 162.5 & 193.2 & 323.6 & - & 388.7 & - & - & - \\
\hline Rapeseed meal & 30.0 & 30.0 & 60.0 & - & 60.0 & - & - & - \\
\hline Soybean meal & 145.0 & 117.5 & 292.5 & - & 232.5 & - & - & - \\
\hline Wheat middlings & 120.0 & 120.0 & 240.0 & - & 240.0 & - & - & - \\
\hline Calcium carbonate & 18.0 & 15.0 & 35.5 & - & 30.0 & - & - & - \\
\hline Salt & 2.0 & 2.0 & 4.5 & - & 4.0 & - & - & - \\
\hline Dicalcium phosphate & 13.0 & 13.0 & 25.5 & - & 26.0 & - & - & - \\
\hline Sodium bicarbonate & 1.0 & 1.0 & 2.0 & - & 2.0 & - & - & - \\
\hline Methionine & 1.7 & 1.9 & 3.4 & - & 3.9 & - & - & - \\
\hline Lysine & 1.3 & 1.4 & 2.5 & - & 2.9 & - & - & - \\
\hline Threonine & 0.5 & - & 0.5 & - & - & - & - & - \\
\hline Additive & 2.0 & 2.0 & 4.0 & - & 4.0 & - & - & - \\
\hline Vitamin and mineral premix & $3.0^{\mathrm{f}}$ & $3.0^{\mathrm{f}}$ & $6.0^{\mathrm{f}}$ & - & 6.0 & - & $11.1^{\mathrm{g}}$ & $8.6^{\mathrm{g}}$ \\
\hline Water & & & & & & & 667.0 & 754.0 \\
\hline \multicolumn{9}{|c|}{ Potential environmental impacts (per kg at the farm gate) } \\
\hline Global warming (g CO 2 -eq.) & 536.0 & 436.0 & 532.0 & & 432.0 & & 339.0 & 192.0 \\
\hline Eutrophication potential ( $\mathrm{g} \mathrm{PO}_{4}$-eq.) & 4.6 & 5.0 & 4.6 & & 5.0 & & 3.0 & 3.3 \\
\hline Acidification potential ( $\mathrm{g} \mathrm{SO}_{2}$-eq.) & 3.8 & 3.2 & 3.7 & & 3.1 & & 1.9 & 1.0 \\
\hline Terrestrial ecotoxicity (g 1.4-DCB-eq.) & 2.6 & 2.0 & 2.5 & & 1.9 & & 1.7 & 0.9 \\
\hline Primary energy use (MJ) & 5.6 & 4.2 & 5.3 & & 4.0 & & 3.1 & 1.2 \\
\hline Water use (L) & 61.3 & 15.8 & 61.1 & & 15.6 & & 53.4 & 4.4 \\
\hline Land occupation ( $\mathrm{m}^{2}$ year) & 1.2 & 1.4 & 1.2 & & 1.4 & & 0.7 & 0.9 \\
\hline
\end{tabular}

a CM: complete pelleted diet containing 50\% maize; CS: complete pelleted diet containing 50\% sorghum; MM: mixed-ration diet containing 50\% maize mash (“CF”) and 50\% protein-rich pellets ("PRM") MS: mixed-ration diet containing 50\% sorghum whole seeds ("SWS") and 50\% protein-rich pellets ("PRS").

b Arroyo et al., 2012a.

c Arroyo et al., 2013b.

d $420 \mathrm{~g}$ maize/ $\mathrm{kg}$ as whole grains and $580 \mathrm{~g}$ maize $/ \mathrm{kg}$ as ground meal.

e $420 \mathrm{~g}$ sorghum $/ \mathrm{kg}$ as whole seeds and $580 \mathrm{~g}$ sorghum/ $\mathrm{kg}$ as ground meal.

${ }^{f}$ Vitamins, A: $9990 \mathrm{UI} / \mathrm{kg}$; D3: $1998 \mathrm{UI} / \mathrm{kg} ; \mathrm{E}: 10.0 \mathrm{UI} / \mathrm{kg} ; \mathrm{B} 1: 2.0 \mathrm{mg} / \mathrm{kg} ; \mathrm{K3}: 1.0 \mathrm{mg} / \mathrm{kg}$; B2: $2.5 \mathrm{mg} / \mathrm{kg} ;$ B5: $5.1 \mathrm{mg} / \mathrm{kg} ;$ B6: $1.0 \mathrm{mg} / \mathrm{kg} ;$ PP: 24.9 mg/kg; B9: 0.3 mg/kg; Choline: $300 \mathrm{mg} / \mathrm{kg}$. Dietary minerals, Cu: $9.3 \mathrm{mg} / \mathrm{kg} ; \mathrm{Fe}: 29.0 \mathrm{mg} / \mathrm{kg} ; \mathrm{I}: 0.99 \mathrm{mg} / \mathrm{kg} ; \mathrm{Co}: 0.16 \mathrm{mg} / \mathrm{kg}$; Mn: $70 \mathrm{mg} / \mathrm{kg} ; \mathrm{Zn}: 47 \mathrm{mg} / \mathrm{kg} ; \mathrm{Se}: 0.20 \mathrm{mg} / \mathrm{kg} 4000 \mathrm{mg} / \mathrm{kg}$; Clay (sepiolite): 2 g/kg.

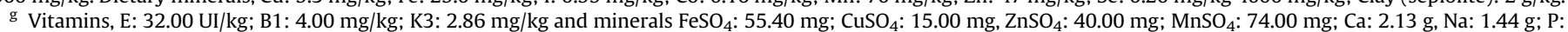
$0.23 \mathrm{~g} / \mathrm{kg}$.

Table 2

Main inputs used, dry matter yield, nitrate-N emitted (all in $\mathrm{kg} / \mathrm{ha}$ except irrigation) and potential environmental impacts (for $1 \mathrm{~kg}$ delivered at the feed mill) for maize and sorghum production.

\begin{tabular}{lll}
\hline & & \\
\hline Inputs (kg/ha except irrigation) & Maize $^{\mathrm{a}}$ & Sorghum $^{\mathrm{b}}$ \\
$\mathrm{N}$ Mineral & & \\
$\mathrm{N}$ & 189.0 & 68.0 \\
$\mathrm{P}_{2} \mathrm{O}_{5}$ (triple superphosphate) & 46.0 & 23.0 \\
$\mathrm{~K}_{2} \mathrm{O}$ (potassium oxide) & 67.0 & 21.0 \\
$\mathrm{CaO}$ (calcium oxide) & 85.0 & 8.0 \\
$\mathrm{Seed}$ for sowing & 167.0 & 333.0 \\
Pesticide (active ingredient) & 20.0 & 13.0 \\
Diesel & 3.1 & 2.2 \\
Irrigation water (m $\left.{ }^{3} / \mathrm{ha}\right)$ & 82.0 & 76.0 \\
Agricultural machinery & 760.0 & 0.0 \\
Grain dry matter yield (kg/ha) & 20.9 & 19.0 \\
Nitrate-N emitted (kg/ha) & 8820.0 & 5525.0 \\
Potential environmental impacts (per kg) & 70.0 & 32.0 \\
Global warming potential (g CO & \\
Eutrophication potential (g PO & & \\
Acidification potential (g SO & & 327.0 \\
Terrestrial ecotoxicity (g 1.4-DCB-eq.) & 527.0 & 5.8 \\
Primary energy use (MJ) & 4.9 & 1.7 \\
Water use (L) & 3.0 & 1.5 \\
Land occupation (m ${ }^{2}$ year) & 2.7 & 1.8 \\
\hline
\end{tabular}

a Irrigated, from Aquitaine region, France.

b Not irrigated, from Midi-Pyrénées region, France. and $-61 \%)$ and the WU (-74\% and $-92 \%)$ for the diet production. Conversely, the diet presentation form, i.e. mainly the grinding and pelleting process for the cereal part of the diet, had only a very slight effect on the impact values $(<-5 \%$ in MM vs. CM or MS vs. $\mathrm{CM}$, respectively; data not shown).

\subsection{Production of goose foie gras}

Our study was conducted on different scenarios introducing a change in routine foie gras goose farm practices by partial and/or total substitution of maize by sorghum and modification of the diet presentation, based on experimental data from two studies (Arroyo et al., 2012a, 2013b). The foie gras production process map is given in Fig. 1.

\subsubsection{Routine farm management}

The breeding system we defined (based on traditional practices; Magdeleine, 2003) for the production of goose eggs was located in a rural zone of the Dordogne assumed to be located $80 \mathrm{~km}$ from the farm (i.e. from the goose GF and $\mathrm{O}$ units). The average breeding unit surface area was 1 ha, and the bird buildings covered an area of $250 \mathrm{~m}^{2}$. The infrastructure materials of the sheds consisted mainly of steel tubes, brick, polyvinyl chloride, polyurethane, and concrete for the foundations. The shelters were fitted with luminositycontrol systems to maximize egg-laying. The feeding and drinking systems were fully automated. The composition of the feed distributed during breeding is described in Sauveur et al. (1988). A 


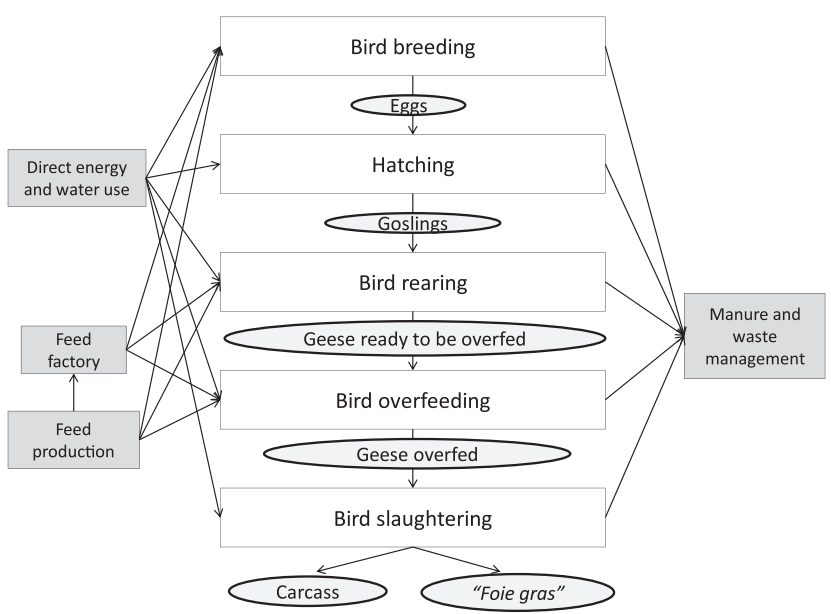

Fig. 1. Flow diagram process-mapping goose foie gras production from the cradle to the slaughterhouse exit gate.

flock of breeding geese comprised 800 reproductive geese that lived for 4 years and produced 29,700 eggs per year. The manure extracted from the breeding unit represented $120 \mathrm{~kg} / \mathrm{bird} /$ year and were allocated inside and outside the building regarding outdoor access of animals.

The hatchery was located $80 \mathrm{~km}$ from the farm. The building occupied $600 \mathrm{~m}^{2}$. The construction materials of the sheds consisted mainly of steel tubes, brick, polyvinyl chloride, polyurethane, and concrete for the foundations. About 170,550 eggs were incubated per year, ultimately producing 113,500 day-old goslings.

Both the GF and $O$ units were located on the same farm. Each rearing cycle lasted about 105 days, allowing 3 production cycles of 1000 birds per year. Grower geese of both sexes were used. The rearing building covered an area of $250 \mathrm{~m}^{2}$, and each flock had access to 2 ha of grassland. Room temperature was maintained at $28{ }^{\circ} \mathrm{C}$ during the first week after hatching and was subsequently gradually reduced to $22^{\circ} \mathrm{C}$ at 49 days of age, after which no heat was provided and geese had access to the outdoors.

Each O-period cycle lasted about 15 days, allowing 12 production cycles of 400 geese per year. The building used for the overfeeding covered a $200 \mathrm{~m}^{2}$ surface area and was divided into 40 pens $(3 \times 1 \mathrm{~m}$ per pen, holding 10 geese) fitted with drinkers. The internal climate was $20^{\circ} \mathrm{C}$ and $90 \%$ max. humidity. The bird performance during the $\mathrm{GF}$ and $\mathrm{O}$ periods used in this paper come from experimental data and are described below. The waste extracted represented $40 \mathrm{~kg} / \mathrm{bird}$ of manure and $70 \mathrm{~L} /$ bird of slurry for the GF and $\mathrm{O}$ units, respectively. During the GF period, manure was allocated inside and outside the building regarding outdoor access of animals.

The energy use data related to breeding, hatching, rearing, overfeeding and slaughtering steps were collected from experts from the industry according to average practices (Magdeleine, 2003). The quantities of $N$ and $C$ excreted were calculated from CORPEN (2006) and Gac et al. (2006), and gaseous emissions were calculated according to Gac et al. (2006), IPCC (2006), IPCC (2007), taking into account the difference between liquid (slurry) and solid (manure) waste, and the location of the manure (inside or outside the building) as presented by Meda et al. (2011). Due to similar energy and protein contents between experimental diets (Arroyo et al., 2012a; 2013b) as well as similar manure management between scenarios, we assumed that the emission factors were similar between groups.

The bird slaughtering unit was assumed to be located $80 \mathrm{~km}$ from the farm. The building covered a $320 \mathrm{~m}^{2}$ surface area. About 80,000 overfed geese were killed per year in accordance with
European Council (EC) regulation No. 1099/2009, to yield carcasses and foie gras. For this process, environmental interventions were allocated using the economic value of these two co-products. ISO 14044 standard (ISO, 2006) recommended the use of economic allocation only as a last resort but it seems very appropriate in the case of foie gras production since this co-product represents only $10 \%$ of the weight but, as a luxury product, $80 \%$ of the economic value of the animal ( $900 \mathrm{~g}$ vs. $8220 \mathrm{~g}$ and $50 € / \mathrm{kg}$ vs. $1.5 € / \mathrm{kg}$ at the slaughter house gate). Such a choice refers to the function of this particular product in the economic sphere as highlighted by Ardente and Cellura (2012). However, to evaluate the influence of the allocation rule on the LCA results, both economic and mass allocations were conducted on two scenarios of the study (maizebased or sorghum-based growing-finishing diet).

\subsubsection{Scenarios for the study of the effects of diet presentation on foie gras production}

The rearing performances used to build the diet presentation scenarios were taken from Arroyo et al. (2012a). The aim of this trial (study A) was to study the effects of cereal (maize or sorghum) included in the diet, and the effect of diet presentation (a complete pelleted diet or a simplified diet in the form of a 50:50 mixture of cereal whole grains and protein-rich pellets) during the GF period on goose performance. 240 ganders were divided into four groups according to a $2 \times 2$ factorial design (the first letter of the group name refers to the form of the diet and the second letter refers to the cereal type: $\mathrm{CMM}_{\mathrm{a}}$ group (complete pelleted diet with maize); $\mathrm{MMM}_{\mathrm{a}}$ group (mixture diet with maize); $\mathrm{CSM}_{\mathrm{a}}$ group (complete pelleted diet with sorghum); $\mathrm{MSM}_{\mathrm{a}}$ group (mixture diet with sorghum). After this period, 33 birds/group were overfed with maize (the third letter of the group name $M$ refers to the use of maize for overfeeding). The main results, which are reported in Table 3, show that diet presentation form had no effect on body weight or foie gras weight at the end of the 0 period, but increased mortality during the $O$ period $(+10$ or +20 pts depending on cereal type; for more details, see Arroyo et al., 2012a).

\subsubsection{Scenarios for the study of the effects of cereals used in the diet} on foie gras production

The rearing performances used to build the cereal types scenarios were taken from Arroyo et al. (2013b). The aim of this trial (study B) was to study the effects of cereal (maize or sorghum) included in the diet given during the GF period and/or the $O$ period. In this experiment, the diet offered during the GF period was in form of a complete pelleted feed. A total of 260 geese were divided into four groups according to a $2 \times 2$ factorial design: $\mathrm{CMM}_{\mathrm{b}}$ group (maize during GF and O periods); $\mathrm{CSM}_{\mathrm{b}}$ group (sorghum during GF period and maize during $\mathrm{O}$ period); $\mathrm{CMS}_{\mathrm{b}}$ group (maize during GF period and sorghum during $\mathrm{O}$ period); and $\mathrm{CSS}_{\mathrm{b}}$ group (sorghum during GF and $O$ periods). The main results, which are reported in Table 3, showed that birds overfed with sorghum yielded heavier foie gras than birds overfed with maize $(+11 \%)$ but mortality was higher in the $\mathrm{CSM}_{\mathrm{b}}$ group compared to the other 3 groups (14.3\% vs. $<6.2 \%$; for more details, see Arroyo et al., 2013b).

\subsection{Life cycle impact assessment}

The LCA concerns the production of $1 \mathrm{~kg}$ of foie gras, defined as functional unit, from egg production through to evisceration of the birds at the slaughterhouse, including diet production and the transport of inputs.

Life cycle impact assessment was carried out using the CML2 method (Hischier and Weidema, 2009) in SimaPro (version 7.2; Frischknecht et al., 2007). The list of impact categories considered includes GWP (g CO 2 -eq.), EP (g $\mathrm{PO}_{4}$-eq.), acidification potential 
Table 3

Goose performance according to feeding strategies.

\begin{tabular}{|c|c|c|c|c|c|c|c|c|}
\hline & \multicolumn{4}{|c|}{ Effect of diet presentation $^{\mathrm{a}}$} & \multicolumn{4}{|c|}{ Effect of cereal type in the diet ${ }^{b}$} \\
\hline & Group $\mathrm{CMM}_{\mathrm{a}}$ & Group $\mathrm{CSM}_{\mathrm{a}}$ & Group $\mathrm{MMM}_{\mathrm{a}}$ & Group $\mathrm{MSM}_{\mathrm{a}}$ & Group $\mathrm{CMM}_{\mathrm{b}}$ & Group $\mathrm{CMS}_{\mathrm{b}}$ & Group $\mathrm{CSM}_{\mathrm{b}}$ & Group $\mathrm{CSS}_{\mathrm{b}}$ \\
\hline Diet during GF period ${ }^{\mathrm{c}}$ & $\mathrm{CM}$ & $\mathrm{CS}$ & MM & MS & $\mathrm{CM}$ & $\mathrm{CM}$ & $\mathrm{CS}$ & CS \\
\hline Diet during $O$ period & Maize & Maize & Maize & Maize & Maize & Sorghum & Maize & Sorghum \\
\hline \multicolumn{9}{|c|}{ Performance during $S$ period } \\
\hline Period & $1-53 \mathrm{~d}$ & & & & $1-43 d$ & & & \\
\hline Feed intake $(\mathrm{g} / \mathrm{bird})^{\mathrm{d}}$ & 11,500 & & & & 8500 & & & \\
\hline \multicolumn{9}{|c|}{ Performance during GF period } \\
\hline Period & $54-101 \mathrm{~d}$ & & & & $44-104 \mathrm{~d}$ & & & \\
\hline Mortality (\%) & 0.83 & 1.67 & 0.83 & 0.00 & 1.65 & 1.65 & 1.15 & 1.15 \\
\hline Feed intake (g/bird) & 10,730 & 11,520 & 11,940 & 11,920 & 11,870 & 11,870 & 12,950 & 12,950 \\
\hline \multicolumn{9}{|c|}{ Performance during $\mathrm{O}$ period } \\
\hline Period & $102-117 \mathrm{~d}$ & & & & $105-120 \mathrm{~d}$ & & & \\
\hline Mortality (\%) & 6.06 & 6.06 & 15.15 & 24.24 & 1.49 & 3.08 & 14.29 & 6.15 \\
\hline Feed intake $(\mathrm{g} / \mathrm{bird})^{\mathrm{e}}$ & 13,920 & 13,810 & 13,780 & 13,800 & 12,725 & 12,699 & 12,759 & 12,773 \\
\hline Body weight $(\mathrm{g})$ & 7968 & 8122 & 8256 & 8219 & 8252 & 8315 & 8224 & 8410 \\
\hline Fatty liver $(\mathrm{g})$ & 858 & 880 & 889 & 816 & 910 & 943 & 860 & 1026 \\
\hline FTR $^{\mathrm{f}}$ & 16.2 & 15.7 & 15.5 & 16.9 & 14.0 & 13.5 & 14.8 & 12.4 \\
\hline
\end{tabular}

S period: starter period; GF period: growing-finishing period; O period: overfeeding period.

a Arroyo et al., 2012a.

b Arroyo et al., 2013b.

c CM: complete pelleted diet containing 50\% maize; CS: complete pelleted diet containing 50\% sorghum; MM mixed-ration diet containing 50\% maize mash and 50\% protein-rich pellets; MS: mixed-ration diet containing 50\% sorghum whole seeds and $50 \%$ protein-rich pellets.

d The starter diet used was a complete pelleted diet, AMEn; (11.70 MJ/kg, CP 18.00\%), manufactured by DFP Nutraliance (Saint-Ybard, Corrèze, France).

e Diet without the water added.

${ }^{\mathrm{f}}$ FTR: Feed Transformation Rate; Feed intake (kg)/Fatty liver (kg).

(AP; g SO 2 -eq.), terrestrial ecotoxicity (TE; g 1,4-DCB-eq.), PEU (MJ), WU $(\mathrm{L})$ and $\mathrm{LO}\left(\mathrm{m}^{2}\right.$ per year). Each impact category was calculated by multiplying the aggregated resources used and aggregated emissions of each individual substance by a characterization factor for each potential target impact category. PEU was calculated according to the Cumulative Energy Demand method, version 1.03 (Frischknecht et al., 2004). For GWP, we updated the values of the characterization factors (Forster et al., 2007) for biogenic methane (new value $25 \mathrm{~kg} \mathrm{CO}$-eq.) and nitrous oxide (new value $298 \mathrm{~kg} \mathrm{CO}$-eq.).

For data analysis, each category of impact was broken down into five classes of inputs: i) Energy class, including fuel for transport of raw materials, feed, eggs, goslings, reared and fattened geese, electricity for lighting the animals, cooling the building, processing the feed and powering the machines, and gas for heating animals during the S period; ii) Feed class, including all inputs necessary to produce the feed ingredients, including the fertilizers and the irrigation water; within the Feed class, impacts were subdivided into the steps of the production process: breeding, S, GF and $\mathrm{O}$ periods; iii) Water class, including the drinking water, the water used to clean the interior of housing and the water in the overfeeding mixture, but excluding irrigation water for crop production; iv) Manure class, corresponding to emissions arising from housing and end use of manure, and v) Housing class, including materials for house building and bedding.

Each impact category was also broken down in the five steps of the production process: breeding, hatching, rearing, overfeeding and slaughtering.

Bird mortality was taken into account in the calculation of the life cycle inventory. It had direct effects on the feed intake, drinking water and manure production while other inputs (transport, housing, energy, water other than drinking) were affected indirectly pro rata. The data of mortality and feed intake, including that of dead birds, during the breeding and hatching stages of production come from the literature. Those concerning the S, GF and $\mathrm{O}$ periods, and the slaughtering stage were measured during the experiments (Arroyo et al., 2012a, 2013b). For example, the average amount of feed intake during the $\mathrm{O}$ period $(12.72,12.70,12.76$ and $12.77 \mathrm{~kg} / \mathrm{bird}$, respectively in groups $\mathrm{CMM}_{\mathrm{b}}, \mathrm{CMS}_{\mathrm{b}}, \mathrm{CSM}_{\mathrm{b}}$, and $\mathrm{CSS}_{\mathrm{b}}$; Table 3) included the total feed $(12.8,14.2,74.3$ and $38.5 \mathrm{~kg}$, respectively) ingested unavailingly by the geese that died $(1,2,9$ and 4 out of 65 geese per group, respectively).

\section{Results}

\subsection{Environmental impacts of standard foie gras production}

In standard conditions, foie gras comes from geese fed maize as their main dietary energy source during both GF and O periods. To evaluate the environmental impacts of standard foie gras production, we therefore averaged results of impacts from $\mathrm{CMM}_{\mathrm{a}}$ and $\mathrm{CMM}_{\mathrm{b}}$ groups (control groups of studies A and $\mathrm{B}$ ). Production of $1 \mathrm{~kg}$ of foie gras induced a GWP of $37.5 \mathrm{~kg} \mathrm{CO}$-eq., an EP of $0.27 \mathrm{~kg} \mathrm{PO}_{4}$-eq., an AP of $0.52 \mathrm{~kg} \mathrm{SO}$-eq., a TE of $0.12 \mathrm{~kg} 1.4$-DCBeq., a PEU of $282 \mathrm{MJ}$, a WU of $2742 \mathrm{~L}$ and an $\mathrm{LO}$ of $48.6 \mathrm{~m}^{2}$ year (Fig. 2).

Inputs associated with feed production contributed to more than $50 \%$ of the impacts of standard foie gras production and up to $90 \%$ for LO, except for AP (26\%; Fig. 3A). AP was mainly explained by Manure class (70\%). Manure class also contributed significantly to EP (30\%) and GWP (33\%). Housing class contributed less than $15 \%$ to all of the impact categories. The direct use of water for watering the animal and cleaning the buildings was very low ( $7 \%$ of WU). The major contribution to WU was Feed class, through needs for maize irrigation. Similarly, direct energy use contributed to only $17 \%$ of PEU, the main contributor to PEU being Feed class (73\%; Fig. 3A).

We divided the impacts due to Feed class inputs between different feeding periods (Fig. 3B). The feed intake during the $\mathrm{S}$ and GF period contributed equally to the impact of Feed class (about $28 \%$ for all impact categories). The 0 period was the main contributor to the impact of Feed class, about 32\% for all impact categories and up to $49 \%$ for WU. These results are closely linked to the respective total feed intake of birds during the $S$ period (11.5 and $8.5 \mathrm{~kg} /$ bird in groups $\mathrm{CMM}_{\mathrm{a}}$ and $\mathrm{CMM}_{\mathrm{b}}$, respectively), GF period 

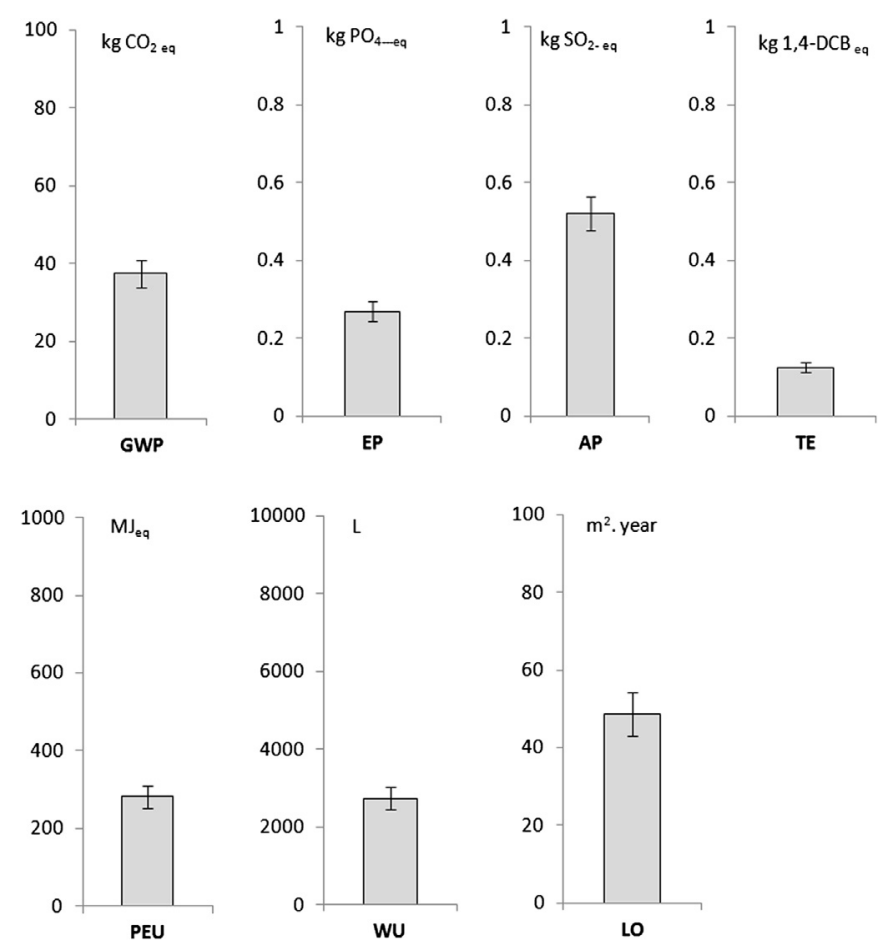

Fig. 2. Potential environmental impacts of $1 \mathrm{~kg}$ foie gras at the slaughterhouse gate, produced in standard conditions. GWP: global warming potential; EP: eutrophication potential; AP: acidification potential; TE: terrestrial ecotoxicity; PEU: primary energy use; WU: water use; LO: land occupation. Error bars refer to standard deviation obtained in the experiments.

(10.7 and $11.9 \mathrm{~kg} / \mathrm{bird}$ ) and $O$ period (13.9 and $12.7 \mathrm{~kg} / \mathrm{bird}$; Table 3 ). The diet intake during the breeding period made the smallest contribution $(<15 \%)$.

Among the different steps in foie gras production (Fig. 1), bird rearing, i.e. the $S+G F$ periods, was the main contributor to all the impact categories (from $46 \%$ for WU to $71 \%$ for AP; Fig. $3 \mathrm{C}$ ) followed by the overfeeding step (from $27 \%$ for PEU to $46 \%$ for WU). The hatching and slaughtering steps contributed to less than $3 \%$ each to all the impact categories.

\subsection{Effects of the form of diet presentation on environmental impacts of foie gras production}

The effects of diet presentation form on the environmental impacts of $1 \mathrm{~kg}$ of foie gras produced were dependent on the cereal type included in the diet. Indeed, diet presentation form had no effect on the environmental impact of foie gras when the cereal used was maize, since difference between $\mathrm{CMM}_{\mathrm{a}}$ and $\mathrm{MMM}_{\mathrm{a}}$ groups were less than $7 \%$ for all impact categories (e.g. for GWP: $40.0 \mathrm{~kg} \mathrm{CO}$-eq vs. $42.8 \mathrm{~kg} \mathrm{CO}$-eq in the $\mathrm{CMM}_{\mathrm{a}}$ and $\mathrm{MMM}_{\mathrm{a}}$ groups, respectively; Table 4). Conversely, a diet presented in a simplified form during the GF period increased by $16-22 \%$ all the impact of foie gras when the cereal used was sorghum, due to a higher bird mortality during the subsequent $\mathrm{O}$ period (e.g. $+21 \%$ for GWP).

\subsection{Effects of cereals used in the diet on environmental impacts of} foie gras production

The effect of cereal type in the goose diet on the environmental impacts of foie gras production were dependent on its level of inclusion and the physiological state of the geese when it was offered. Indeed, a total substitution of maize by sorghum, i.e. through both the GF and the $\mathrm{O}$ periods $\left(\mathrm{CSS}_{\mathrm{b}}\right.$ vs. $\left.\mathrm{CMM}_{\mathrm{b}}\right)$, resulted in lower environmental impacts of foie gras for all the impact categories, except for LO (+7\%; Table 4). The highest reduction was for WU (-62\%) Other impacts, such as GWP $(-17 \%)$; $\mathrm{AP}(-12 \%), \mathrm{TE}(-23 \%)$ and PEU $(-23 \%)$ were more moderate. Reduction of EP $(-2 \%)$ could be considered as below the sensitivity threshold of the LCA to farming conditions (see 3.4.). Conversely, consequences of a partial substitution of maize by sorghum during the $\mathrm{O}$ period $\left(\mathrm{CMS}_{\mathrm{b}} \mathrm{vs}\right.$. $\left.\mathrm{CMM}_{\mathrm{b}}\right)$ on the impact of foie gras were lower than the sensitivity threshold of the LCA to farming conditions for all the impact categories ( $+5 \%$ to $-7 \%$; Table 4 ) except for WU $(-21 \%)$. Finally, the consequences of partial substitution of maize by sorghum during the GF period only $\left(\mathrm{CSM}_{b} \mathrm{Vs} \mathrm{CMM}_{\mathrm{b}}\right)$ on the impact of foie gras were ambivalent. It lowered WU (-29\%; Table 4) but increased LO $(+26 \%), \mathrm{EP}(+20 \%)$ and $\mathrm{AP}(+13 \%)$ mainly due to higher bird mortality ( +13 pts).

\subsection{Sensitivity of the results}

\subsubsection{Allocation method}

The influence of the allocation method, for co-products of both food-processing industry and geese, on environmental impact results was studied for $\mathrm{CMM}_{\mathrm{b}}$ and $\mathrm{CSS}_{\mathrm{b}}$ scenarios (Fig. 4). The use of mass allocation decreased by about 4 times all impact category levels but the difference between the two scenarios remained similar for the two methods. For example, the GWP was 35.0 and $29.2 \mathrm{~kg} \mathrm{CO}$-eq. $/ \mathrm{kg}$ foie gras in groups $\mathrm{CMM}_{\mathrm{b}}$ and $\mathrm{CSS}_{\mathrm{b}}$, respectively, using the economic allocation and 9.1 and $7.6 \mathrm{~kg} \mathrm{CO}$-eq./ $\mathrm{kg}$ foie gras in groups $\mathrm{CMM}_{\mathrm{b}}$ and $\mathrm{CSS}_{\mathrm{b}}$, respectively, using the mass allocation.

\subsubsection{Farming conditions}

Studies A and B have two common experimental groups $\left(\mathrm{CMM}_{\mathrm{a}, \mathrm{b}}\right.$ and $\left.\mathrm{CSM}_{\mathrm{a}, \mathrm{b}}\right)$. The comparison of data for the potential 

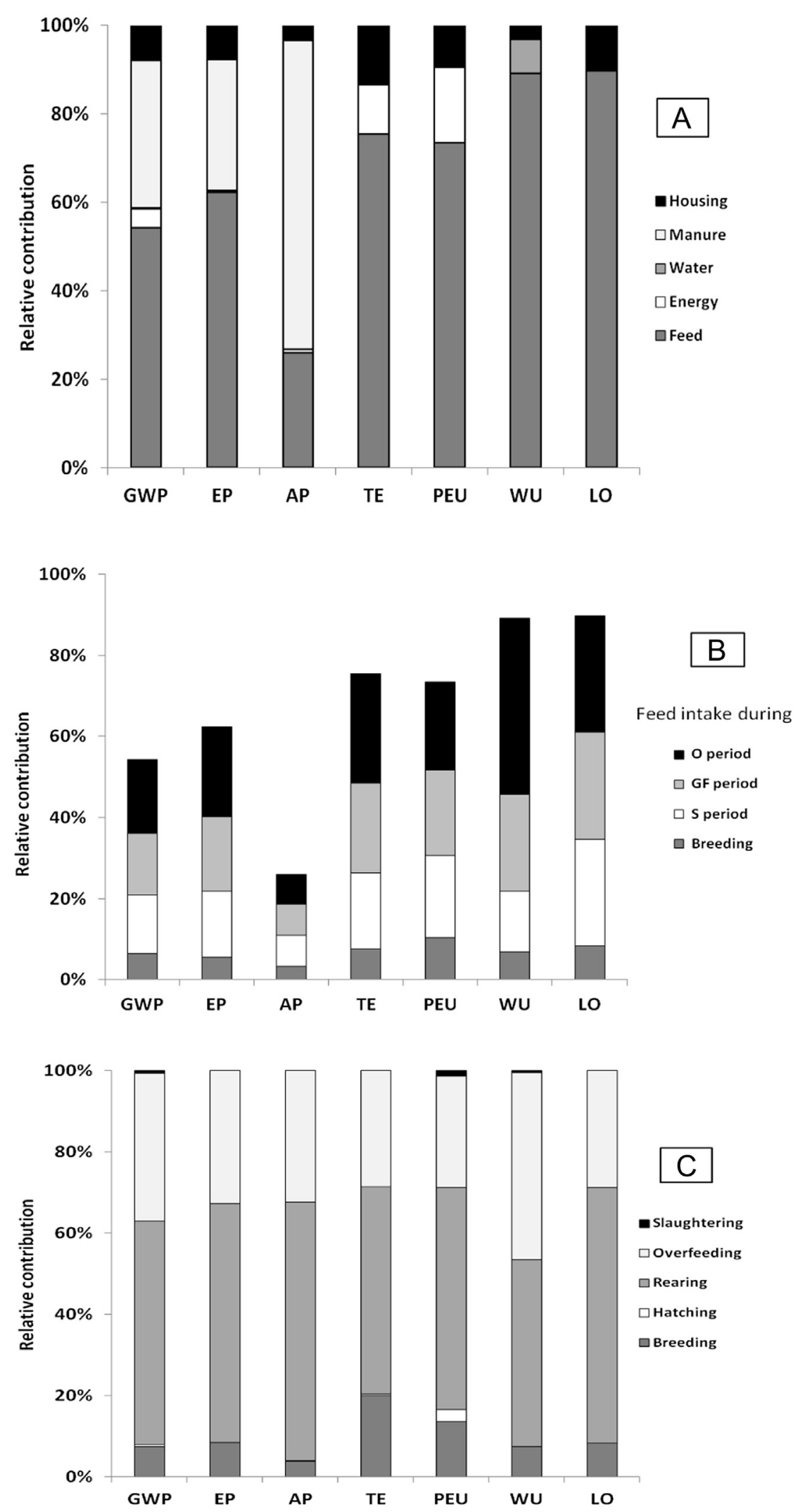

Fig. 3. Contribution of different classes of inputs (A), of different diets within Feed class (B), and of different steps of the production process (C) to the potential environmental impacts of standard foie gras production.). GWP: global warming potential; EP: eutrophication potential; AP: acidification potential; TE: terrestrial ecotoxicity; PEU: primary energy use; WU: water use; LO: land occupation; S period: starter period; GF period: growing-finishing period; O period: overfeeding period. 
Table 4

Potential environmental impacts of foie gras ( $1 \mathrm{~kg}$ at the slaughterhouse gate) according to dietary practices using the economic allocation approach.

\begin{tabular}{|c|c|c|c|c|c|c|c|c|c|}
\hline Group & $\begin{array}{l}\text { Diet during } \\
\text { GF period }^{\mathrm{a}}\end{array}$ & $\begin{array}{l}\text { Diet during } \\
\text { O period }\end{array}$ & $\begin{array}{l}\text { Global warming } \\
\text { potential } \\
\left(\mathrm{kg} \mathrm{CO}_{2} \text {-eq.) }\right.\end{array}$ & $\begin{array}{l}\text { Eutrophication } \\
\text { potential } \\
\text { (kg } \mathrm{PO}_{4} \text {-eq.) }\end{array}$ & $\begin{array}{l}\text { Acidification } \\
\text { potential } \\
\text { (kg SO}{ }_{2} \text {-eq.) }\end{array}$ & $\begin{array}{l}\text { Terrestrial } \\
\text { ecotoxicity } \\
\text { (kg 1.4-DCB-eq.) }\end{array}$ & $\begin{array}{l}\text { Primary } \\
\text { energy } \\
\text { use }(\mathrm{MJ})\end{array}$ & $\begin{array}{l}\text { Water } \\
\text { use (L) }\end{array}$ & $\begin{array}{l}\text { Land } \\
\text { occupation } \\
\text { ( } \mathrm{m}^{2} \text { year) }\end{array}$ \\
\hline \multicolumn{10}{|c|}{ Effect of diet presentation ${ }^{b}$} \\
\hline $\mathrm{CMM}_{\mathrm{a}}$ & $\mathrm{CM}$ & Maize & 40.0 & 0.29 & 0.55 & 0.13 & 302.5 & 2935.8 & 52.7 \\
\hline $\mathrm{CSM}_{\mathrm{a}}$ & CS & Maize & 38.3 & 0.29 & 0.53 & 0.12 & 284.5 & 2396.0 & 54.3 \\
\hline $\mathrm{MMM}_{\mathrm{a}}$ & MM & Maize & 42.8 & 0.30 & 0.57 & 0.14 & 313.4 & 3027.8 & 55.2 \\
\hline $\mathrm{MSM}_{\mathrm{a}}$ & MS & Maize & 46.3 & 0.35 & 0.65 & 0.15 & 342.1 & 2785.2 & 66.5 \\
\hline \multicolumn{10}{|c|}{ Effect of cereal in the diet ${ }^{c}$} \\
\hline $\mathrm{CMM}_{\mathrm{b}}$ & $\mathrm{CM}$ & Maize & 35.0 & 0.25 & 0.49 & 0.12 & 260.7 & 2547.2 & 44.6 \\
\hline $\mathrm{CMS}_{\mathrm{b}}$ & $\mathrm{CM}$ & Sorghum & 33.4 & 0.25 & 0.48 & 0.11 & 244.5 & 2017.2 & 46.7 \\
\hline $\mathrm{CSM}_{\mathrm{b}}$ & CS & Maize & 37.7 & 0.30 & 0.56 & 0.12 & 266.8 & 1801.8 & 56.1 \\
\hline $\mathrm{CSS}_{\mathrm{b}}$ & CS & Sorghum & 29.2 & 0.25 & 0.43 & 0.09 & 200.7 & 976.8 & 47.9 \\
\hline
\end{tabular}

a CM: complete pelleted diet containing 50\% maize; CS: complete pelleted diet containing 50\% sorghum; MM mixed-ration diet containing 50\% maize mash and 50\% protein-rich pellet; MS: mixed-ration diet containing 50\% sorghum whole seeds and $50 \%$ protein-rich pellets.

b Arroyo et al., 2012a.

c Arroyo et al., 2013b.

environmental impacts of foie gras production from these two pairs of groups allows the sensitivity of our results to farming conditions and animal performance to be evaluated. In each group, mortality ( $<2 \%$ during the GF period and $<7 \%$ during the $O$ period except in the $\mathrm{CSM}_{\mathrm{b}}$ group) and weight of fatty liver ( $>850 \mathrm{~g}$ ) were in accordance with national performance (Magdeleine, 2003). Animal performance (feed intake, foie gras weight, mortality) in $\mathrm{CSM}_{\mathrm{a}}$ and $\mathrm{CSM}_{\mathrm{b}}$ groups was very similar and variability of environmental impacts among these groups was less than $6 \%$ (Table 4 ). On the other hand, animal efficiency was higher in $\mathrm{CMM}_{\mathrm{b}}$ than $\mathrm{CMM}_{\mathrm{a}}$ since a lower feed intake during the $\mathrm{O}$ period $(12,725 \mathrm{vs}$. $13,920 \mathrm{~g} / \mathrm{bird}$ ) lead to a higher fatty liver weight (910 g vs. $858 \mathrm{~g}$, respectively). As a consequence, the variability of environmental impacts among these groups was higher for all the impact categories (8-12\% depending on the impact; Fig. 2 and Table 4$)$. The variability of animal performance within standardized farming conditions thus altered environmental impact scores by up to $12 \%$, which can be considered as the threshold of sensitivity of LCA in our study.

\subsubsection{Feed efficiency and mortality}

Feed was shown to be the key variable explaining most environmental impacts except for AP (see 3.1.). Feed could alter impact scores through feed efficiency and bird mortality. The feed transformation ratio during the $\mathrm{O}$ period $(\mathrm{kg}$ of feed intake per $\mathrm{kg}$ of fatty liver) was different between groups (16.2 vs. 14.0 in $\mathrm{CMM}_{\mathrm{a}}$ and $\mathrm{CMM}_{\mathrm{b}}$, respectively; Table 3 ) and also between animals within groups (from 23.0 to 11.7 and 19.5 to 9.1 in $\mathrm{CMM}_{\mathrm{a}}$ and $\mathrm{CMM}_{\mathrm{b}}$, respectively; data not shown). All impact categories increased proportionally. Mortality could act through mortality rate, but also through day of bird death. The higher the mortality rate was and/ or the later the death occurred, the higher was the amount of unavailing feed intake. Mathematical modeling showed that if mortality rate at the end of the $O$ period increases by $+1,+5,+10$ or $+20 \%$, then the impact of Feed inputs necessary to produce $1 \mathrm{~kg}$ of foie gras increases by $+1.01,+5.26,+11.11$ and $+25.00 \%$, respectively (data not shown). If mortality rate increases by $+1 \%$, then the impact of Feed inputs necessary to produce $1 \mathrm{~kg}$ of foie gras increases by only +0.29 or $+0.62 \%$ if it occurs at the at the end of the $\mathrm{S}$ or GF, respectively compared with $+1.01 \%$ if it occurs at the end of the $O$ period. In the present studies, mortality was higher during the $O$ period than during the GF period ( $<2$ vs. $1.5-$ $24 \%$; Table 3 ), and mainly at the end of the $O$ period. Half of the deaths (8/17 and $11 / 16$, in studies A and B, respectively) occurred in the last two days of the $\mathrm{O}$ period or during transport to the slaughter house.

\section{Discussion}

The objectives of this paper were to evaluate with the LCA method the consequences i) of a substitution of maize by sorghum in the diet fed during the GF and/or the $O$ periods and ii) of use of cereal in a simplified form in the diet of the geese during the GF period on environmental impacts of goose foie gras production. The results showed that i) a total substitution of maize decreases the environmental impacts of foie gras production and ii) environmental impacts of the use of cereal in a simplified form during the GF period depended on the cereal used: maize had no effect but sorghum had a detrimental effect.

The environmental impacts of the production of feed for poultry (Mosnier et al., 2011) as well as the consequences of integrating environmental constraints in the feed formulation were previously studied (Nguyen et al., 2012). Results showed that both the choice of raw materials and the form of diet presentation modified the environmental impacts of feed production. Studies have demonstrated the technical feasibility (Gabriel et al., 2003) and environmental value (van der Werf et al., 2005) of using non-pelleted feeds

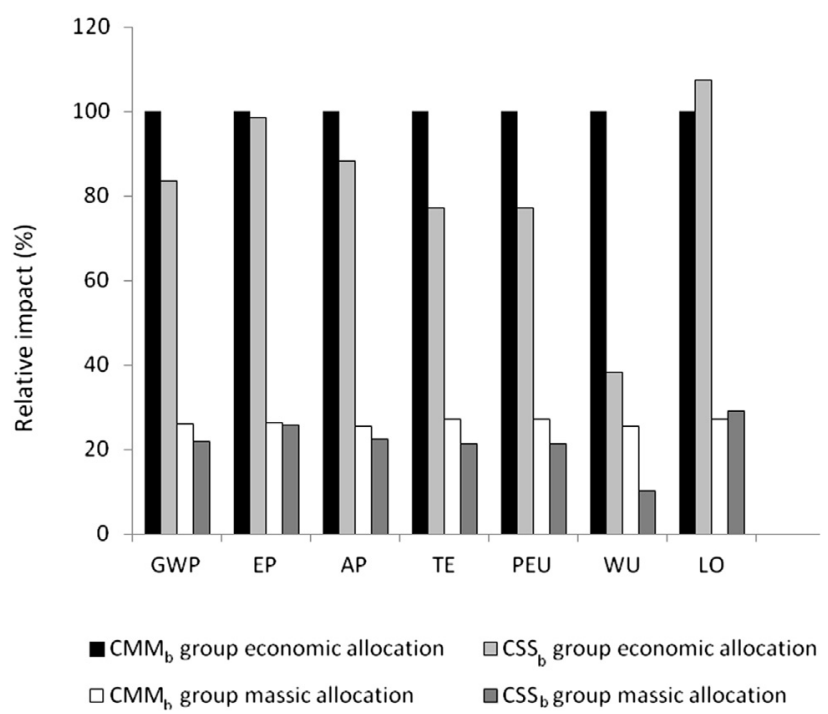

Fig. 4. Relative potential environmental impacts of foie gras (1 kg at the slaughterhouse gate) according to type of grain in the diet (maize: $\mathrm{CMM}_{\mathrm{b}}$ group or sorghum: $\mathrm{CSS}_{\mathrm{b}}$ group), using the economic (eco) or mass allocation procedure. GWP: global warming potential; EP: eutrophication potential; AP: acidification potential; PEU: primary energy use; WU: water use; LO: land occupation. 
(crushed, mashed, or whole grains) in poultry in order to avoid the pelleting process, since industrial processes involved in producing feed ingredients are known to contribute to their environmental impacts (van der Werf et al., 2005). Here, we found that giving a simplified diet during the GF period, in the form of a mixture of whole grains and protein-rich pellets, only slightly reduced the environmental impacts of a feed for geese compared to a complete pelleted diet. Therefore, its consequences in terms of environmental impact of foie gras production were nil, with unchanged zootechnical performance, for maize, or negative with lower zootechnical performance (higher mortality), with sorghum. The use of sorghum in a simplified form may prevent the right development of the proximal part of the goose's digestive tract, meaning the animals are less able to cope with the very high dietary intake during the $O$ period (Arroyo et al., 2012a). A lower hydration capacity of whole grains compared to pellets could explain this result and the higher mortality observed with this feeding schedule. Finally, the better feed efficiency observed during the $G$ period with a simplified diet (Arroyo et al., 2012a) could not compensate for the detrimental effect of bird mortality on environmental impacts.

Previous results showed that using sorghum in goose diet is technically feasible and opens up promising animal performance prospects (Arroyo et al., 2012a; 2013b). Here, we found evidence that a total substitution of maize by sorghum was also beneficial in terms of potential environmental impacts of foie gras production. This difference is observed for the impact on WU, since sorghum culture has a lower water demand than maize crops (Farré and Faci, 2006), but also for many other impacts such as GWP, AP or PEU.

However, a partial substitution, i.e. during the GF period or the $O$ period only, led to contradictory results: it had no effect on the environmental impacts of foie gras when the substitution was used in the $O$ period but had detrimental effects when the substitution was used in the GF period. Therefore, the use of a food with lower environmental impact does not guarantee a reduction in the impacts of livestock production systems if the livestock system efficiency is reduced, for example if mortality or feed intake increased.

Taken together, the results of both studies demonstrate that the theoretical evaluation of anticipated environmental benefits by changing a production process must be verified by testing on animals. Indeed, the regulation of biological functions makes the agricultural systems less predictable than industrial ones which are solely based on physical processes. To reduce the risk of false conclusions, experimental results should also be integrated into LCA only when the innovative process is functional and steady. In our case, the number of animals per group was satisfactory $(>120$ birds). The use of sorghum in the diet of goose was also studied in other experiments (Arroyo et al., 2012c, 2013a, 2013c) making the total number of animals used very high ( $>1000)$. Thus animal performance can be considered meaningful and conclusions robust. However, technical adjustments in feed practices should be tested to recover system efficiency, also when the type of grain included in the diet differs between GF and O periods. So foie gras production would benefit from the environmental value of sorghum. For example, a shortening of the overfeeding period or having a more gradual food transition between GF and O periods, are possible ways to avoid some detrimental effects of sorghum use on geese performance.

Confidence in the LCA results depends primarily on the quality of source data and their pertinence for the system studied (Chen and Corson, 2012). Combining data from many sources, here routine farm management and experimental data, raises the issue of how to assess uncertainty and data approximation and the allied consequences on LCA results (Ross et al., 2002). For example, Prudêncio da Silva et al. (2010) underlined the wide range of different datasets for Brazilian soybeans. The peculiarities of technical and regional practices already have a great influence on the results of LCA. In the present case, uncertainty concerning technical and regional practices within France is very low since Dordogne, the location of our production units, is the main area of French foie gras production, and practices are standardized within the territory and the country. Bulgaria and Hungary are the main producers of goose foie gras in the world (Arroyo et al., 2012b). Although farming practices of goose for foie gras production are homogeneous within France, they differ from those in these two countries: the genetic strain of animals (Maxipalm ${ }^{\circledR}$ vs. Anabest G in France and in the two countries of eastern Europe, respectively), the average weight of foie gras ( $900 \mathrm{vs} .450 \mathrm{~g}$ ), the duration of the rearing period (102-110 vs. 60-80 days) and of the O period (1518 vs. 20-26 days) are different (Leprettre et al., 2002; Áprily et al., 2009). No data are available regarding the potential environmental impacts of goose foie gras production in the countries of eastern Europe, but for the reasons stated above, we can suppose that they are different from those of goose foie gras produced in France.

In the present work, scenarios differed according to the composition or form of the diets and were tested on animals during in vivo experiments. We refer to two experiments (Arroyo et al., 2012a, 2013b) with common experimental groups (CMM and CSM). The comparison of data for the potential environmental impacts of $1 \mathrm{~kg}$ of foie gras from these two pairs of groups provides information on the sensitivity of the LCA to farming conditions. The variations between groups were about 3\% and 12\% (Table 4) depending on impact category in the case of the GF diet based on sorghum or maize, respectively. The greatest variation, i.e. $12 \%$, can be considered as the threshold of the LCA method in our conditions, and corresponds to the normal variability of the biological response of birds to changes in the environment (temperature, nutritional composition of raw material, etc) despite the standardization of breeding practices. Therefore, variations of environmental impacts for foie gras production between different groups should not be considered as significant, and were not discussed here, when they are above or below this threshold.

The key variable explaining most of the environmental impacts, except for AP, is Feed class and its related inputs as previously shown by Leinonen et al. (2012a, 2012b). The quantity of feed necessary to produce foie gras, and thus impact scores, depends on feed efficiency, i.e. efficiency to transform overfeeding mixture into fatty liver, and mortality, both through the mortality rate and the day of bird death. These results confirm the importance of improving system efficiency, besides impacts of raw materials entering the composition of diets, to reduce the environmental impact of livestock production systems (Garnett, 2012).

Finally, the main source of uncertainty in the data chain concerns the methodological choices in LCA. This issue has previously been studied in grassland pastoral systems for cattle (Subak, 1999; Peters et al., 2010). The range of different regions, breed types, and levels of management and technical efficiency make it difficult to draw definitive conclusions (Crosson et al., 2011). The present study focused on links between feeding strategy and animal performance. Data concerning the cereal type, their production process and efficiency were obtained according average French practices. However, considerable uncertainty exists in this field and could have been included in the LCA calculation.

The present work is the first attempt to evaluate the environmental impact of goose foie gras production. The review of de Vries and de Boer (2010) together with the results of Leinonen et al. (2012a, 2012b) allows the comparison between the environmental impacts of goose foie gras and meat production of the present work with other livestock products (Fig. 5). The goose meat production (i.e. the carcass) induces similar or lower environmental impacts than other livestock products. On the other 

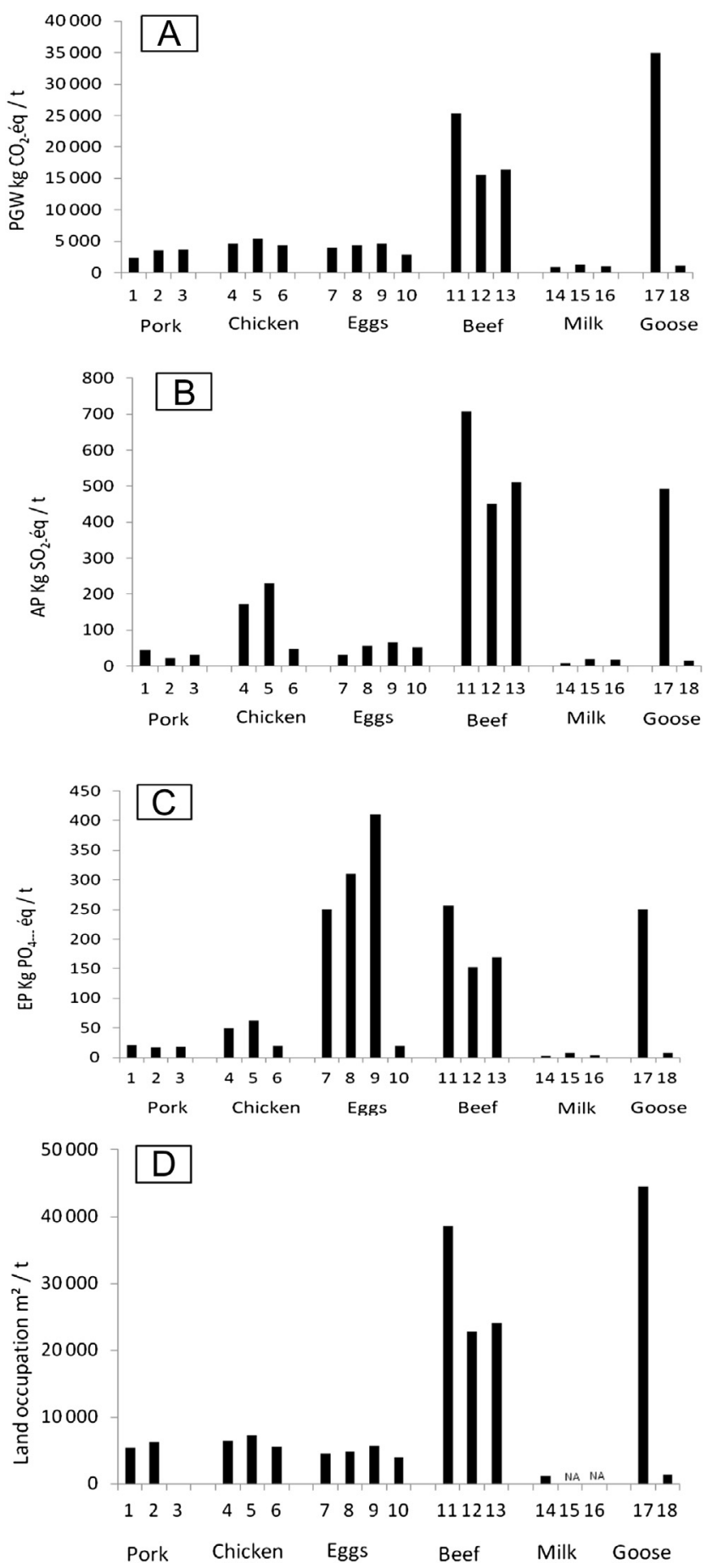

Fig. 5. Global warming potential (GWP; A), acidification potential (AP; B), eutrophication potential (EP; C) and land occupation (D) for livestock products (adapted to de Vries and de Boer, 2010; Leinonen et al., 2012a, 2012b). Numero refers to differen production systems and studies. Pork - 1: Good agricultural practice; 2: Red label; 3 . conventional. Chicken - 4: Conventional; 5: Free range; 6: Conventional. Eggs - 7: Battery cages; 8: Deep litter; 9: Deep litter with outdoor run; 10: Battery cages. Beef 11: $100 \%$ suckler; 12: Free range; 13: Conventional. Milk - 14: Average farm; 15: Intensive; 16: extensive. Goose - 17: Foie gras; 18: Meat. Data from Blonk et al. (1997; $3)$, Haas et al. $(2001 ; 15,16)$, Basset-Mens and van der Werf $(2005 ; 1,2)$, Mollenhorst et al. $(2006 ; 7,8,9)$, Williams et al. $(2006 ; 4,5,11,12,13)$, Basset-Mens et al. $(2009 ; 14)$, Leinonen et al. (2012a, 2012b; 6, 10), Present study (CMM group : 17, 18).

hand, foie gras production induces higher GWP and LO than other livestock products, as well as similar AP to beef and similar GWP to beef and eggs. This could be explained both by the allocation procedure and farming practices. Indeed, unlike other monogastric animals, like chicken or pigs, geese have outdoor access during rearing, are raised nearly to puberty before slaughter and the endproduct is fatty. All these factors reduce the feed conversion ratio, increase the amount of resources needed and therefore the environmental impacts. No reference is available concerning the environmental impacts of duck foie gras. Lower impacts than for goose foie gras are likely, due to the higher efficiency and shorter GF and $\mathrm{O}$ periods in the duck than in the goose farming system (Guy et al., 1995).

These high impacts of foie gras production and the difference between the two co-products from goose, meat and foie gras, can also be explained as a consequence of their monetary value, which is taken into account in the economic allocation. This procedure allocates $80 \%$ of impact of the production system to the foie gras although it represents only $10 \%$ of animal weight. Our results confirm that the allocation method for the calculation of environmental impact using LCA method has a great influence on the results as previously discussed (Pelletier and Tyedmers, 2011; Ardente and Cellura, 2012). The use of mass allocation would have decreased all impact category levels by about 4 times, without change the overall conclusion about the effects of diet. Since the foie gras is a luxury product that is consumed in a timely manner usually during festive times, the choice of economic allocation better take into account the value of each co-product in the economic sphere and consequently the objective of the production activity.

On a worldwide scale, production of foie gras is very low (27,100 $\mathrm{t}$ in 2011; CIFOG, 2012) compared to that of chicken meat $(80,000,000 \mathrm{t})$ or pork $(106,000,000 \mathrm{t}$; FAO, 2013). Therefore, in spite of a high GWP per kg, foie gras generates 4 and 3000 times less $\mathrm{CO}_{2}$-eq production in the world than chicken or pork meat production. Nevertheless, Jungbluth et al. (2012) demonstrate that the suppression of luxury foods, i.e. not necessary from a nutritional point of view such as coffee, alcohol, fatty snacks etc. could reduce by $5 \%$ the environmental impacts of food consumption.

\section{Conclusions}

The present study is the first attempt to evaluate the environmental impacts of goose foie gras production and consequences of changes in feeding practises. The results reported here show that changes in goose feeding practices could contribute to a more environmentally-friendly production system of foie gras provided they do not degrade animal performance. In particular, the total substitution of maize by sorghum in the diet of growing and overfed geese reduced the potential environmental impacts of the foie gras production process as a whole. Sorghum therefore offers a useful alternative to maize in goose feeding, especially under conditions of limited water availability, by reducing the environmental impacts and increasing the range of available food sources and thus the flexibility and robustness of the foie gras production system. However, using current rearing practices, the use of a diet presented in a simplified form can increase the environmental impact of the foie gras production processes if it is associated with detrimental effects on bird mortality as observed with sorghum. Hence the use of sorghum in a simplified form requires developing appropriate feeding practices before it can be recommended.

\section{Acknowledgments}

The authors thank the staff of the goose breeding station (Dordogne, France) for excellent supervision of the studies on geese, the staff of the Chambre d'Agriculture de la Dordogne for collecting data on goose foie gras production, the staff of UMR 1069 SAS for their technical assistance on the LCA analysis and Mathilde Brachet for her help in data analysis. 


\section{References}

AGRESTE, [La statistique, l'évaluation et la prospective agricole], 2010. Enquête pratiques culturales. Retrieved May 20, 2012, from. http://agreste.agriculture. gouv.fr/.

Althaus, H.J., Chudacoff, M., Hischier, R., Jungbluth, N., Osses, M., Primas, A., 2007. Final ecoinvent data report v2.0. Life Cycle Inventories of Chemicals, vol. 8. Swiss Centre for the Life Cycle Inventories, Dübendorf, Switzerland.

Amigues, J.P., Debaeke, P., Itier, B., Lemaire, G., Seguin, B., Tardieu, F., Thomas, A., 2006. Sécheresse et agriculture. Réduire la vulnérabilité de l'agriculture à un risque accru de manque d'eau. Expertise scientifique collective, synthèse du rapport. INRA, France, p. 72

Áprily, S., Szász, S., Bogenfürst, F., 2009. Effect of genotype, sex and cramming preparation on performance and fatty liver production in geese. Arch Geflügelk 73, 268-274.

Ardente, F., Cellura, M., 2012. Economic allocation in life cycle assessment. J. Ind. Ecol. 16, 387-398.

Arroyo, J., Auvergne, A., Dubois, J.P., Lavigne, F., Bijja, M., Bannelier, C., FortunLamothe, L., 2012a. Effects of presentation and type of cereals (corn or sorghum) on performance of geese. Poult. Sci. 91, 2063-2071.

Arroyo, J., Fortun-Lamothe, L., Dubois, J.P., Lavigne, F., Auvergne, A., 2012b. Schedule and management of food transitions in geese for the production of foie gras. INRA Prod. Anim. 25, 419-430.

Arroyo, J., Auvergne, A., Dubois, J.P., Lavigne, F., Bijja, M., Fortun-Lamothe, L., 2012c. Influence of feeding sorghum on the growth, gizzard development and carcass traits of growing geese. Animal 6, 1583-1589.

Arroyo, J., Auvergne, A., Dubois, J.P., Lavigne, F., Bijja, M., Bannelier, C., FortunLamothe, L., 2013a. The influence of loose-mix feeding on behavior, feed intake and body weight of growing geese. Poult. Sci. 92, 1454-1460.

Arroyo, J., Auvergne, A., Dubois, J.P., Lavigne, F., Bijja, M., Bannelier, C., Manse, H., Fortun-Lamothe, L., 2013b. Effects of substituting yellow corn for sorghum in geese diets on magret and foie gras quality. Poult. Sci. (in press).

Arroyo, J., Auvergne, A., Dubois, J.P., Lavigne, F., Bijja, M., Fortun-Lamothe, L., 2013c. Influence of amount and form of sorghum in the diet on the performance of overfed geese. J. Appl. Poult. Res. (submitted for publication).

Basset-Mens, C., van der Werf, H.M.G., 2005. Scenario-based environmental assessment of farming systems: the case of pig production in France. Agric. Ecosyst. Environ. 105, 127-144.

Basset-Mens, C., van der Werf, H.M.G., Robin, P., Morvan, T., Hassouna, M., Paillat, J., Vertès, F., 2007. Methods and data for the environmental inventory of contrasting pig production systems. J. Clean. Prod. 15, 1395-1405.

Basset-Mens, C., Ledgard, S., Boyes, B., 2009. Eco-efficiency of intensification scenarios for milk production in New Zealand. Ecol. Econ. 68, 1615-1625.

Blonk, H., Lafleur, M., van Zeijts, H., 1997. Towards an Environmental Infrastructure of the Dutch Food Industry: Exploring the Information Conversion of Five Food Commodities. IVAM Environmental Research. University of Amsterdam, Amsterdam, The Netherlands.

Boggia, A., Paolotti, L., Castellini, C., 2010. Environmental impact evaluation of conventional, organic and organic-plus poultry production systems using life cycle assessment. World's Poult. Sci. J. 66, 95-114.

Chen, X., Corson, M., 2012. Analysis and propagation of uncertainty in agricultural LCA (Poster). In: Corson, M.S., van der Werf, H.M.G. (Eds.), Proc. 8th Int. Conference on LCA in the Agri-food Sector, 1-4 October 2012, Saint-Malo, France, p. 933.

CIFOG (Comité Interprofessionnel des palmipèdes à Foie Gras), 2012. Rapport économique 2011. Assemblée Générale du 22/06/2012. Saint Palais France.

CORPEN, 2006. Estimation des rejets d'azote, de phosphore, de potassium, de calcium, de cuivre et de zinc par les élevages avicoles. Comité d'orientation pour les pratiques agricoles respectueuses de l'environnement, p. 55.

Crosson, P., Shalloo, L., O'Brienb, D., Lanigan, G.J., Foley, P.A., Boland, T.M., Kenny, D.A., 2011. A review of whole farm systems models of greenhouse gas emissions from beef and dairy cattle production systems. Anim. Feed Sci. Technol. 166-167, 29-45.

European Union Council Directive 1009/2009/EC, 2009. On the protection of animals at the time of slaughter or killing. Off. J. EC L 303, 1-30.

FAO, 2002. Technical Conversion Factors (TCF) for Agricultural Commodities. Retrieved May 18, 2010, from. http://www.fao.org/fileadmin/templates/ess/ documents/methodology/tcf.pdf.

FAO, 2013. Statistics Division. Production of Pig Meat and Chicken Meat. Retrieved April 20, 2013, from. www.fao.org

Farré, I., Faci, J.M., 2006. Comparative response of maize (Zea mays L.) and sorghum (Sorghum bicolor L. Moench) to deficit irrigation in a Mediterranean environment. Agric. Water Manag. 83, 135-144.

Forster, P., Ramaswamy, V., Artaxo, P., Berntsen, T., Betts, R., Fahey, D.W., Haywood, J., Lean, J., Lowe, D.C., Myhre, G., Nganga, J., Prinn, R., Raga, G., Schulz, M., van Dorland, R., 2007. Changes in atmospheric constituents and in radiative forcing. In: Solomon, S., Qin, D., Manning, M., Chen, Z., Marquis, M., Averyt, K.B., Tignor, M., Miller, H.L. (Eds.), Climate Change 2007: the Physical Science Basis. Contribution of Working Group I to the Fourth Assessment Report of the Intergovernmental Panel on Climate Change. Cambridge University Press, Cambridge, UK and New York, NY, USA, pp. 129-234.

Frischknecht, R., Jungbluth, N., Althaus, H.J., Doka, G., Dones, R., Hirschier, R., Hellweg, S., Humbert, S., Margni, M., Nemecek, T., Speilmann, M., 2004. Implementation of Life Cycle Impact Assessment Methods (Version 1.1). EcoInvent Report No. 3. Swiss Centre for Life Cycle Inventories, Dübendorf, p. 116.
Frischknecht, R., Jungbluth, N., Althaus, H.J., Bauer, C., Doka, G., Dones, R., Hischier, R., Hellweg, S., Humbert, S., Köllner, T., Loerincik, Y., Margni, M., Nemecek, T., 2007. Implementation of Life Cycle Impacts Assessment Methods. Ecoinvent report no. 3, v2.0. Swiss Centre for Life Cycle Inventories, Dübendorf, Switzerland.

Gabriel, I., Mallet, S., Leconte, M., 2003. Differences in the digestive tract characteristics of broiler chickens fed on complete pelleted diet or on whole wheat added to pelleted protein concentrate. Br. Poult. Sci. 44, 283-290.

Gac, A., Béline, F., Bioteau, T., 2006. Greenhouse Gases and Ammonia Emissions from Livestock Waste Management: Bibliography Review and Data Base Development. Final Report. ADEME, p. 98. retrieved April 21, 2013, from. ftp://195.6.33.4/pub/ dce/piaheco/NOPOLU-CR-2008-29\%20octobre/Etude_ADEME_BDgaz2006.pdf.

Garnett, T., 2012. Three perspectives on sustainable food security: efficiency, demand restraint, food system transformation. What role for LCA? In: Corson, M.S., van der Werf, H.M.G. (Eds.), Proc. 8th Int. Conference on LCA in the Agri-Food Sector, 1-4 October 2012, Saint-Malo, France, pp. 15-25.

Guéméné, D., Guy, G., 2004. The past, present and future of force-feeding and "foie gras" production. World's Poult. Sci. J. 60, 210-222.

Guy, G., Rousselot-Pailley, D., Gourichon, D., 1995. Comparison of geese, mule duck and muscovy duck after cramming. Ann. Zootech. 44, 297-305.

Haas, G., Wetterich, F., Köpke, U., 2001. Comparing intensive, extensified and organic grassland farming in southern Germany by process life cycle assessment. Agric. Ecosyst. Environ. 83, 43-53.

Hischier, R., Weidema, B.P., May 2009. Implementation of Life Cycle Assessment Methods, Data V2.1. Ecoinvent report $\mathrm{n}^{\circ} 3$, St. Gallen.

Information Science, Technology and Applications (ISTA), 2009. Oil World Annual 2009, vol. 1. ISTA Mielke GmbH, Hamburg, Germany.

IPCC, 2006. Chapter 10. Emissions from livestock and manure management. In: Eggleston, H.S., Buendia, L., Miwa, K., Ngara, T., Tanabe, K. (Eds.), 2006 IPCC Guidelines for National Greenhouse Gas Inventories, Intergovernmental Panel on Climate Change. IGES, Japan, p. 87.

IPCC, 2007. 2007 IPCC Synthesis Report, Intergovernmental Panel on Climate Change, p. 52.

ISO, 2006. Environmental Management - Life Cycle Assessment - Requirements and Guidelines (ISO 14044:2006). European Committee for Standardization, Brussels, p. 20.

Jungbluth, N., Chudacoff, M., Dauriat, A., Dinkel, F., Doka, G., Faist Emmenegger, M., Gnansounou, E., Kljun, N., Schleiss, K., Spielmann, M., Stettler, C., Sutter, J., 2007. Life Cycle Inventories of Bioenergy. Ecoinvent report 17. Swiss Centre for Life Cycle Inventories, Dübendorf, Switzerland.

Jungbluth, N., Itten, R., Schori, S., 2012. Environmental impacts of food consumption and its reduction potentials. In: Corson, M.S., van der Werf, H.M.G. (Eds.), Proc. 8th Int. Conference on LCA in the Agri-food Sector, 1-4 October 2012, SaintMalo, France, pp. 104-115.

Lammers, P.J., 2011. Life-cycle assessment of farrow-to-finish pig production systems: a review. CAB Rev. Perspect. Agric. Vet. Sci. Nutr. Nat. Resour. 6, 1-8.

LCA Food database, 2007. Retrieved May 18, 2010, from: http://www.lcafood.dk/.

Leinonen, I., Williams, A.G., Wiseman, J., Guy, J., Kyriazakis, I., 2012a. Predicting the environmental impacts of chicken systems in the United Kingdom through a life cycle assessment: broiler production systems. Poult. Sci. 91, 8-25.

Leinonen, I., Williams, A.G., Wiseman, J., Guy, J., Kyriazakis, I., 2012b. Predicting the environmental impacts of chicken systems in the United Kingdom through a life cycle assessment: egg production systems. Poult. Sci. 91, 26-40.

Leprettre, S., Dubois, J.P., Bouillier-Oudot, M., Babilé, R., 2002. Technique de gavage des oies: incidence de la fréquence des repas et de la durée de gavage sur les performances et les caractéristiques technologiques et organoleptiques des foies gras. In: Proc. 5èmes Journées de la Recherche sur les Palmipèdes à Foie Gras. Pau, France, pp. 122-125.

Magdeleine, P., 2003. Contexte, structure et perspectives d'évolution du secteur français du foie gras, p. 67. Retrieved February 11, 2008, from. http://www.itavi. asso.fr/economie/references/palmipedes.php/.

Meda, B., Hassouna, M., Aubert, C., Robin, P., Dourmad, J.Y., 2011. Influence of rearing conditions and manure management practices on ammonia and greenhouse gas emissions from poultry houses. World's Poult. Sci. J. 67, 441-455.

Mollenhorst, H., Berentsen, P.B.M., de Boer, IJ.M., 2006. On-farm quantification of sustainability indicators: an application to egg production systems. Br. Poult. Sci. 47, 405-417.

Mosnier, E., van der Werf, H.M.G., Boissy, J., Dourmad, J.Y., 2011. Evaluation of the environmental implications of the incorporation of feed-use amino acids in the manufacturing of pig and broiler feeds using Life Cycle Assessment. Animal 5, 1972-1983.

Nemecek, T., Kägi, T., 2007. Life Cycle Inventories of Swiss and European Agricultural Production Systems. Ecoinvent final report v2.0, no. 15, Agroscope Reckenholz-Taenikon Research Station ART. Swiss Centre for Life Cycle Inventories, Zurich and Dübendorf, Switzerland.

Nguyen, T.T.H., Bouvarel, I., Ponchant, P., van der Werf, H.M.G., 2012. Using environmental constraints to formulate low-impact poultry feeds. J. Clean. Prod. 28, 215-224.

Pelletier, N., Tyedmers, P., 2011. An ecological economic critique of the use of market information in life cycle assessment research. J. Ind. Ecol. 15, 342-354.

Peters, G.M., Rowley, H.V., Wiedemann, S., Tucker, R., Short, M.D., Schulz, M., 2010. Red meat production in Australia: life cycle assessment and comparison with overseas studies. Environ. Sci. Technol. 44, 1327-1332.

Prudêncio da Silva, V., van der Werf, H.M.G., Spies, A., Soares, S.R., 2010. Variability in environmental impacts of Brazilian soybean according to crop production and transport scenarios. J. Environ. Manag. 91, 1831-1839. 
Ross, S., Evans, D., Webber, M., 2002. How LCA studies deal with uncertainty. Int. J. LCA 7, 47-52.

Sauvant, D., Perez, J.M., Tran, G. (Eds.), 2004. Tables of Composition and Nutritive Value of Feed Materials: Pigs, Poultry, Cattle, Sheep, Goats, Rabbits, Horses, Fish. INRA Editions/Wageningen Academic Publishers, Paris/The Netherlands, p. 304.

Sauveur, B., Rousselot-Pailley, D., Larrue, P., 1988. Energy feeding of geese breeders. INRA Prod. Anim. 1, 209-214.

Subak, S., 1999. Global environmental costs of beef production. Ecol. Econ. 30, 79-91. de Vries, M., de Boer, I.J.M., 2010. Comparing environmental impacts for livestock products: a review of life cycle assessments. Livestock Sci. 128, 1-11.

van der Werf, H.M.G., Petit, J., Sanders, J., 2005. The environmental impacts of the production of concentrated feed: the case of pig feed in Bretagne. Agric. Syst. 83, 153-177.

Williams, A.G., Audsley, E., Sandars, D.L., 2006. Determining the Environmental Burdens and Resource Use in the Production of Agricultural and Horticultura Commodities. Main Report Defra Research Project ISO205. Cranfield University and Defra, Bedford. 